\title{
Short communication: Effect of lactose on the spray drying of Lactococcus lactis in dairy matrices
}

\author{
E. Martins, ${ }^{1}$ D. C. Cnossen, ${ }^{1}$ C. R. J. Silva, ${ }^{1}$ M. Vakarelova, ${ }^{2}$ and A. F. Carvalho ${ }^{1 *}$ \\ ${ }^{1}$ Department of Food Technology, Universidade Federal de Viçosa (UFV), Viçosa, MG, 36570-977, Brazil \\ ${ }^{2}$ Sphera Encapsulation S.r.l., Verona, 37134, Italy
}

\section{ABSTRACT}

The effects of unfavorable conditions responsible for the viability loss of Lactococcus cells during spray drying can be minimized by the application of dairy matrices as encapsulating materials. This study aimed to evaluate the use of dairy matrices with different lactose contents on the survival of Lactococcus lactis during drying and storage. The use of hydrolyzed-lactose milk resulted in notable loss of cell viability (3.90 log cycles). However, milk enriched with lactose or without fat showed better protection (viability loss between 0.26 and $1.41 \log \mathrm{cfu} / \mathrm{g}$ ) and greater cell survival during storage at room temperature. The enrichment of milk with lactose seems to be ideal for the drying of heat-sensitive bacteria.

Key words: cell viability loss, storage, lactose hydrolysis

\section{Short Communication}

Lactococcus lactis is known for its high acidification potential, caseinolytic and lipolytic activities, and inhibition of pathogenic bacteria (Attar et al., 2018). In most cases, the use of L. lactis as a starter culture depends on its preservation by dehydration, which must ensure high viability and metabolic activity of the cells (Carvalho et al., 2004). Freeze drying is the preferred method to dehydrate lactic acid bacteria because it causes less stress to the cells; however, large-scale use of freeze drying is limited by the high energy costs and long production times (Carvalho et al., 2004; Ziaee et al., 2019).

The energy cost of spray drying is one-tenth of that of freeze drying, and spray drying can operate in continuous mode, which is advantageous in an industrial process (Schuck et al., 2013). However, during the drying, L. lactis is subjected to unfavorable conditions

Received May 9, 2019.

Accepted June 13, 2019.

*Corresponding author: afc1800@yahoo.com responsible for sequential injuries to the cells. To overcome this drawback, dairy matrices have been proposed as encapsulating materials capable of protecting lactic acid bacteria against harmful spray-drying conditions (Maciel et al., 2014; Tavares et al., 2014; Zheng et al., 2015).

Although the protective mechanism of milk is still not well defined, studies suggest that calcium can stabilize cellular structures and combine with milk proteins to form agglomerates with cells, decreasing the stress caused by dehydration and high temperatures (Huang et al., 2016). The heat protection properties of milk are usually associated with its proteins (Khem et al., 2015), but the role played by the other dairy components is poorly understood and might also be important.

This study aimed to evaluate the effect of the encapsulating properties of dairy matrices containing different lactose contents on the survival of spray-dried $L$. lactis. We also investigated the protective behavior of these matrices during storage.

Lactococcus lactis ssp. lactis, isolated from artisanal cheese (Martins et al., 2018), was selected because of its known thermosensitivity. An aliquot of $100 \mu \mathrm{L}$ of the strain was transferred to $10 \mathrm{~mL}$ of de Man, Rogosa, and Sharpe broth (MRS, Difco, Bordeaux, France) and incubated at $30^{\circ} \mathrm{C}$ for $18 \mathrm{~h}$. An aliquot of $2.5 \mathrm{~mL}$ of this pre-activated culture was inoculated into $250 \mathrm{~mL}$ of MRS broth and incubated at $30^{\circ} \mathrm{C}$ for $18 \mathrm{~h}$. The cell suspension was centrifuged $(5,000 \times g$ for $10 \mathrm{~min}$ at $25^{\circ} \mathrm{C}$; Eppendorf, Hamburg, Germany) and the pellet (cell concentrate) was washed twice in saline solution $0.85 \%$ (wt/vol).

The encapsulating matrices (EM) were produced from whole or skim milk powders containing 37.5 and $51 \%$ (wt/wt) lactose, respectively (Itambé Laticínios, Minas Gerais, Brazil; Table 1). Encapsulating matrix without lactose $\left(\mathbf{E M}_{\mathbf{0} \%}\right)$ was produced by lactose hydrolysis using $\beta$-galactosidase (Prozyn, São Paulo, Brazil) at $0.6 \%$ (wt/wt) for $4 \mathrm{~h}$ at $4^{\circ} \mathrm{C}$ (Fialho et al., 2017). Encapsulating matrix with $17 \%$ (wt/wt) of lactose was prepared by dissolution of $100 \mathrm{~g}$ of whole milk powder in $125 \mathrm{~g}$ of distillated water (Table 1). Matrices 
Table 1. Composition of drying medium (encapsulating matrices)

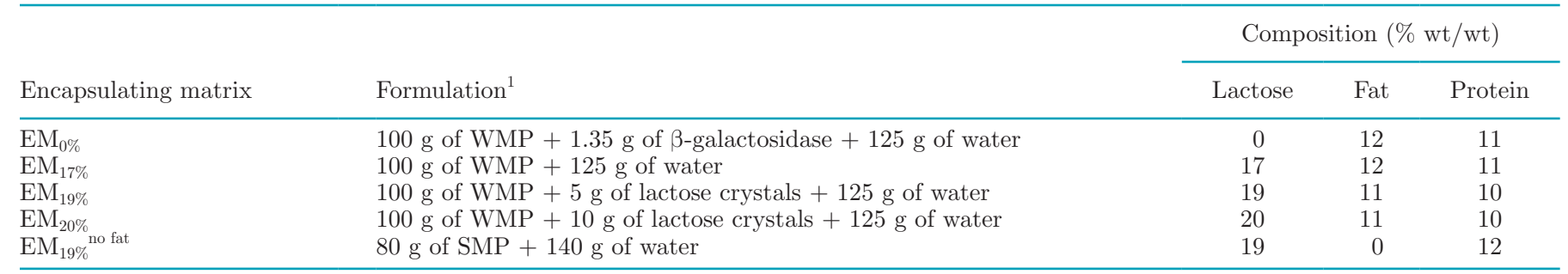

${ }^{1} \mathrm{WMP}=$ whole milk powder; SMP $=$ skim milk powder.

containing 19 or $20 \%$ (wt/wt) lactose $\left(\mathbf{E M}_{\mathbf{1 9 \%}}\right.$ and $\mathbf{E M}_{20 \%}$ ) were prepared by addition of lactose crystals (Cromoline, São Paulo, Brazil). Encapsulating matrix without fat $\left(\mathbf{E M}_{19 \%}{ }^{\text {no fat }}\right)$ was produced by dissolution of $80 \mathrm{~g}$ of skimmed milk powder in $140 \mathrm{~g}$ of distilled water. All matrices were treated at $85^{\circ} \mathrm{C}$ for $1 \mathrm{~h}$ and kept at $40^{\circ} \mathrm{C}$ for inoculation of the cell concentrate.

Cell suspensions (cell concentrate + EM) containing $\sim 10^{9} \mathrm{cfu} / \mathrm{g}$ were dried in a spray-dryer (MSD 1.0, Labmaq, Ribeirão Preto, Brazil) by using inlet air at $130^{\circ} \mathrm{C}$ and a cell suspension flow rate of $0.6 \mathrm{~kg} / \mathrm{h}$, as proposed by Martins et al. (2019). The powder was recovered in sterile bottles and stored at 4 or $25^{\circ} \mathrm{C}$.

The water activity of powders was determined at $25^{\circ} \mathrm{C}$ using an Aqualab water activity meter (Decagon Devices Inc., Pullman, WA), and moisture was determined by heating $3 \mathrm{~g}$ of cell suspension or $1.5 \mathrm{~g}$ of powder at $105^{\circ} \mathrm{C}$ for $5 \mathrm{~h}$ (Schuck et al., 2005). Moisture (M\%) was calculated by determining weight loss after heating, expressed in percentage, and dry extract (DE, in \%) was determined as follows: $\mathrm{DE}=100-\mathrm{M} \%$.

An aliquot of $1 \mathrm{~mL}$ of cell concentrate or $1 \mathrm{~g}$ of powder was dispersed in $9 \mathrm{~mL}$ of saline solution $0.85 \%$ (wt/vol) and serial dilutions were performed. Viable cells were enumerated in microdroplets in MRS agar incubated at $30^{\circ} \mathrm{C}$ for $72 \mathrm{~h}$. The number of viable cells was calculated in relation to DM content (cfu/g) of the concentrate or powder. Cell viability loss was determined as follows: Viability $\operatorname{loss}=\log N_{0}-\log N^{\prime}$, where $N_{0}$ and $N^{\prime}$ represent the number of surviving L. lactis (cfu/g) in the cell concentrate and after drying, respectively. Cell viability during storage was evaluated by the difference between initial and final populations after $45 \mathrm{~d}$ of storage.
Drying was carried out in triplicate samples and results were evaluated by ANOVA and Tukey test $(P$ $<0.05$ ) using the PAST software (Palaeontological Association, Oslo, Norway).

Lactose hydrolysis $\left(\mathrm{EM}_{0 \%}\right)$ resulted in greater loss of cell viability (3.90 log cycles) followed by EM containing $17 \%$ lactose (1.41 log cycles; Figure 1A). Matrices $\mathrm{EM}_{19 \%}, \mathrm{EM}_{20 \%}$ or $\mathrm{EM}_{19 \%}{ }^{\text {no fat }}$ showed the smallest cell viability losses $(\sim 0.26 \log$ cycles; Figure $1 \mathrm{~A})$.

Hydrolysis converts the disaccharide lactose to glucose and galactose, thus increasing the osmotic pressure of the carrier, as predicted by the van't Hoff law. The greater difference in osmotic pressure between cells and the drying medium intensifies the osmotic stress suffered by L. lactis. Furthermore, hydrolysis reduces the encapsulating action of the dairy matrix, leaving cells more susceptible to heat and oxidation.

By increasing the concentration of lactose from 17 to $19 \%$, the cell viability loss decreased from 1.41 to 0.26 $\log \mathrm{cfu} / \mathrm{g}$ (Figure 1A). Thus, it is possible that 17\% lactose was not sufficient to cover all cells. No difference was found between $\mathrm{EM}_{19 \%}$ and $\mathrm{EM}_{20 \%}$; therefore, lactose appears to reach a critical concentration $(\sim 19 \%)$ for cell recovery (Figure 1A).

The treatment without fat $\left(\mathrm{EM}_{19 \%}{ }^{\text {no fat }}\right)$ did not differ statistically from that with the same lactose concentration but with fat $\left(\mathrm{EM}_{19 \%}\right.$; Figure $\left.1 \mathrm{~A}\right)$. Thus, even though fat is protective against heat, we could not confirm this heat protection aspect.

The effect of lactose on the survival of spray-dried bacteria is still being explored and there is no consensus on its effect (Ananta et al., 2005; Ghandi et al., 2013; Zheng et al., 2015). The protective effect is related to

Table 2. Mean values with SEM of the moisture content of powders produced with different dairy encapsulating matrices (EM; Table 1)

\begin{tabular}{lccccc}
\hline & \multicolumn{4}{c}{ Sample } \\
\cline { 2 - 5 } Item & $\mathrm{EM}_{0 \%}$ & $\mathrm{EM}_{17 \%}$ & $\mathrm{EM}_{19 \%}$ & $\mathrm{EM}_{20 \%}$ & $\mathrm{EM}_{19 \%^{\text {no fat }}}$ \\
\hline Moisture $(\%, \mathrm{wt} / \mathrm{wt})$ & $5.55 \pm 0.00^{\mathrm{a}}$ & $2.85 \pm 0.00^{\mathrm{b}}$ & $2.81 \pm 0.00^{\mathrm{b}}$ & $2.83 \pm 0.00^{\mathrm{b}}$ & $3.36 \pm 0.00^{\mathrm{b}}$ \\
\hline${ }_{\mathrm{a}, \mathrm{b}}$ Different letters indicate a significant difference between values of moisture $(P<0.05)$.
\end{tabular}




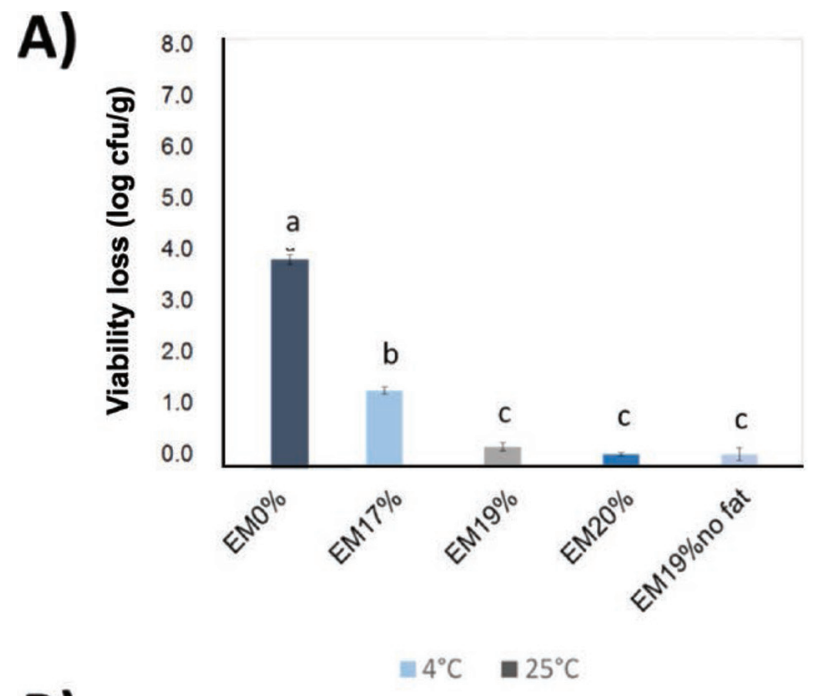

stabilization of the membrane and cell macromolecules by hydrogen bonding at previously occupied sites of water (Rudolph and Crowe, 1985). Nevertheless, our findings suggest another protective mechanism, based on its covering property of cells.

Storage temperature $\left(4\right.$ or $\left.25^{\circ} \mathrm{C}\right)$ had no effect on cell viability loss, except in $\mathrm{EM}_{0 \%}$ (Figure 1B). Studies on the use of hydrolyzed-lactose milk as an encapsulating material are not available in literature; however, this behavior could be explained by the lower glass transition temperature $\left(\mathbf{T}_{\mathrm{Tg}}\right)$ of powders compared with milk powders containing lactose (Roos, 2002; Schuck et al., 2005). Hydrolyzed-lactose milk powder undergoes glass transition at a lower temperature $\left(36^{\circ} \mathrm{C}\right.$ when in equilibrium with air of $11 \%$ of relative humidity) compared with ordinary milk powder $\left(61^{\circ} \mathrm{C}\right.$ under the same equilibrated conditions; Fernández et al., 2003). Thus, it is believed that the hydrolyzed-lactose milk powder underwent glass transition when stored at $25^{\circ} \mathrm{C}$. The change from the vitreous to the amorphous state leads to a decrease in viscosity, which exposes bacteria to environmental conditions (oxygen, light). Water has a very low $\mathrm{T}_{\mathrm{Tg}}\left(-135^{\circ} \mathrm{C}\right)$; thus, water content should be kept low, particularly in $\mathrm{EM}_{0 \%}$, which has a $\mathrm{T}_{\mathrm{Tg}}$ inferior to the other encapsulating materials tested. The moisture analysis (Table 2) showed that the hydrolyzedlactose milk powder had a higher water content, which reinforces the hypothesis of glass transition at $25^{\circ} \mathrm{C}$.

Counts of approximately $10^{8} \mathrm{cfu} / \mathrm{g}$ were observed in powders with greater lactose content $\left(\mathrm{EM}_{19 \%}, \mathrm{EM}_{20 \%}\right.$, and $\mathrm{EM}_{19 \%}{ }^{\text {no fat }}$ ) after $45 \mathrm{~d}$ of storage (Figure 1C). Lactococcus lactis is known to be sensitive to oxygen (Rochat et al., 2005), and lactose protects cells not only against drying damage but also against oxidative stress during storage.

Milk supplementation with lactose seems to be ideal for drying heat-sensitive bacteria, such as L. lactis. In contrast, hydrolyzed-lactose dairy matrices are not an efficient means to preserve cells during drying and storage, probably because of the low $\mathrm{T}_{\mathrm{Tg}}$ of the material. Taking into account the thermosensitivity of the strain used, the application of lactose in encapsulating matrices is a promising approach to make feasible the industrial production of spray-dried bacteria.

\section{ACKNOWLEDGMENTS}

Encapsulation matrix

Figure 1. Cell viability loss of Lactococcus lactis after spray drying (A) and during storage (B), and (C) viable population of L. lactis after $45 \mathrm{~d}$ of storage. Different letters (a-d) indicate statistical differences among the treatments $(P<0.05)$. Error bars indicate the SEM. EM $=$ encapsulating matrices prepared according to the formulations in Table 1 .

The authors are grateful for the financial support provided by Coordenação de Aperfeiçoamento de Pessoal de Nível Superior (CAPES, financial code 001; Brasília, Brazil), Conselho Nacional de Desenvolvimento Científico e Tecnológico (CNPq; Brasília, Brazil), and Fundação de Amparo à Pesquisa do Estado de 
Minas Gerais (FAPEMIG; Belo Horizonte, Brazil) to carry out this research.

\section{REFERENCES}

Ananta, E., M. Volkert, and D. Knorr. 2005. Cellular injuries and storage stability of spray-dried Lactobacillus rhamnosus GG. Int. Dairy J. 15:399-409.

Attar, M. A., M. Yavarmanesh, A. Mortazavi, M. R. Edalatian Dovom, and M. B. Habibi Najafi. 2018. Antibacterial effects of Lactococcus lactis isolated from Lighvan cheese regarding the recognition of nisin, lacticin and lactococcin structural genes. Lebensm. Wiss. Technol. 89:186-191.

Carvalho, A. S., J. Silva, P. Ho, P. Teixeira, F. X. Malcata, and P. Gibbs. 2004. Relevant factors for the preparation of freeze-dried lactic acid bacteria. Int. Dairy J. 14:835-847.

Fernández, E., C. Schebor, and J. Chirife. 2003. Glass transition temperature of regular and lactose hydrolyzed milk powders. Lebensm. Wiss. Technol. 36:547-551.

Fialho, T. L., E. Martins, A. C. P. Silveira, C. R. J. Silva, I. T. Perrone, P. Schuck, and A. F. Carvalho. 2017. Lactose-hydrolyzed milk powder: Thermodynamic characterization of the drying process. Dry. Technol. 36:1688-1695.

Ghandi, A., I. B. Powell, M. Broome, and B. Adhikari. 2013. Survival, fermentation activity and storage stability of spray dried Lactococcus lactis produced via different atomization regimes. J. Food Eng. 115:83-90.

Huang, S., C. Cauty, A. Dolivet, Y. Le Loir, X. D. Chen, P. Schuck, G. Jan, and R. Jeantet. 2016. Double use of highly concentrated sweet whey to improve the biomass production and viability of spray-dried probiotic bacteria. J. Funct. Foods 23:453-463.

Khem, S., M. W. Woo, D. M. Small, X. D. Chen, and B. K. May. 2015. Agent selection and protective effects during single droplet drying of bacteria. Food Chem. 166:206-214.
Maciel, G. M., K. S. Chaves, C. R. F. Grosso, and M. L. Gigante. 2014 Microencapsulation of Lactobacillus acidophilus La-5 by spray-drying using sweet whey and skim milk as encapsulating materials. J. Dairy Sci. 97:1991-1998.

Martins, M. C. F., R. Freitas, J. C. Deuvaux, M. R. Eller, L. A. Nero, and A. F. Carvalho. 2018. Bacterial diversity of artisanal cheese from the Amazonian region of Brazil during the dry and rainy seasons. Food Res. Int. 108:295-300.

Rochat, T., A. Miyoshi, J. Gratadoux, P. Duwat, S. Sourice, V. Azevedo, and P. Langella. 2005. High-level resistance to oxidative stress in Lactococcus lactis conferred by Bacillus subtilis catalase KatE. Microbiology 151(Pt. 9):3011-3018.

Roos, Y. H. 2002. Importance of glass transition and water activity to spray drying and stability of dairy powders. Lait 82:475-484.

Rudolph, A. S., and J. H. Crowe. 1985. Membrane stabilization during freezing: The role of two natural cryoprotectants, trehalose and proline. Cryobiology 22:367-377.

Schuck, P., E. Blanchard, A. Dolivet, S. Méjean, E. Onillon, and R. Jeantet. 2005. Water activity and glass transition in dairy ingredients. Lait 85:295-304.

Schuck, P., A. Dolivet, S. Mejean, C. Herve, and R. Jeantet. 2013. Spray drying of dairy bacteria: New opportunities to improve the viability of bacteria powders. Int. Dairy J. 31:12-17.

Tavares, G. M., T. Croguennec, A. F. Carvalho, and S. Bouhallab. 2014. Milk proteins as encapsulation devices and delivery vehicles: Applications and trends. Trends Food Sci. Technol. 37:5-20.

Zheng, X., N. Fu, M. Duan, M. W. Woo, C. Selomulya, and X. D Chen. 2015. The mechanisms of the protective effects of reconstituted skim milk during convective droplet drying of lactic acid bacteria. Food Res. Int. 76:478-488.

Ziaee, A., A. B. Albadarin, L. Padrela, T. Femmer, E. O'Reilly, and G. Walker. 2019. Spray drying of pharmaceuticals and biopharmaceuticals: Critical parameters and experimental process optimization approaches. Eur. J. Pharm. Sci. 127:300-318. 